\title{
ANALISIS PENERAPAN PSAK 50 DAN PSAK 55 ATAS CADANGAN KERUGIAN PENURUNAN NILAI
}

\author{
Yusni Husain \\ Jullie J. Sondakh \\ Heince Wokas
}

\begin{abstract}
Fakultas Ekonomi Jurusan Akuntansi
Universitas Sam Ratulangi Manado

Email:yusnihusain@yahoo.com
\end{abstract}

\begin{abstract}
ABSTRAK
Penerapan standar akuntansi baru berpengaruh pada perbankan yang merupakan konvergensi dengan International Financial Reporting Standards dan dibahas dalam International Accounting Standards (IAS) 39 mengenai financial instrumen recognition and measurement. Dewan Standar Akuntansi Keuangan telah menerbitkan Pernyataan Standar Akuntansi Keuangan (PSAK) 50 dan 55 mengenai Penyajian, Pengakuan dan Pengukuran Instrumen Keuangan yang akan berlaku efektif pada tanggal 1 Januari 2012. Cadangan Kerugian Penurunan Nilai (Impairment Loss) adalah jumlah yang diturunkan dari nilai tercatat hingga menjadi sebesar nilai yang dapat diperoleh kembali dari aset. Penelitian ini dilakukan pada PT. Bank Mandiri Unit Datulolong Lasut 1 Manado (Persero) Tbk. Tujuan dari penelitian ini untuk mengetahui sejauh mana penerapan PSAK 50 dan PSAK 55 atas pengakuan, pengukuran, serta penyajian cadangan kerugian penurunan nilai PT. Bank Mandiri Unit Datulolong Lasut 1 Manado (Persero) Tbk. Hasil penelitian menunjukkan penerapan PSAK 50 dan PSAK 55 atas Cadangan Kerugian Penurunan Nilai oleh PT. Bank Mandiri Tbk. telah sesuai dengan standar yang berlaku. Proses pengakuan Cadangan Kerugian Penurunan Nilai sebesar nilai diamortisasi menggunakan suku bunga efektif,. Pengukuran tingkat penurunan nilai kolektif untuk aset keuangan dihitung berdasarkan kerugian historis.dilakukan secara kolektif. Penyajian nilai piutang dalam laporan keuangan adalah nilai setelah dikurangi dengan cadangan kerugian penurunan nilai.
\end{abstract}

\section{Kata kunci : Pengakuan, Pengukuran, Penyajian, Cadangan Kerugian Penurunan Nilai}

ABSTRACT

The application of the new accounting standards that are influential in the banking convergence with International Financial Reporting Standards and International Accounting Standards discussed in (IAS) 39 on recognition and measurement of financial instruments. Financial Accounting Standards Board issued Statement of Financial Accounting Standards ( SFAS) 50 and 55 of the Presentation, Recognition and Measurement of Financial Instruments will be effective on January 1, 2012. Allowance for Impairment (Impairment Loss) is derived from the value of the amount to be recorded at recoverable value of the asset. This research was conducted at PT. Bank Mandiri Unit 1 Datulolong Lasut Manado ( Persero ) Tbk. The purpose of this study was to determine the extent of the application of SFAS 50 and SFAS 55 to the recognition, measurement and presentation of the allowance for impairment losses PT. Bank Mandiri Unit 1 Datulolong Lasut Manado ( Persero ) Tbk. The results suggest the application of SFAS 50 and SFAS 55 top Allowance for Impairment Losses by PT Bank Mandiri Tbk. compliance with applicable standards. The process of recognition of Allowance for Impairment Losses at amortized value using the effective interest rate. Measuring the level of collective impairment for financial assets is calculated based on the loss historical collectively. Presentation of receivables in the financial statements is the value after deducting the allowance for impairment losses.

Keywords: Recognition, Measurement, Presentation, Allowance for Impairment Losses 


\section{PENDAHULUAN}

\section{Latar Belakang}

Perkembangan perekonomian nasional yang senantiasa bergerak cepat, kompetitif, dan terintegrasi dengan tantangan yang semakin kompleks serta sistem keuangan yang semakin maju, diperlukan penyesuaian kebijakan di bidang ekonomi, termasuk perbankan. Berdasarkan dengan apa yang tersebut dalam Undang Undang Perbankan Nomor 10 Tahun 1998 tentang perubahan atas Undang-undang Nomor 7 Tahun 1992 tentang perbankan bagian menimbang huruf (a) dan (b) maka, pelaksanaan pembangunan nasional harus memperhatikan keserasian, keselarasan, dan keseimbangan unsur-unsur pembangunan termasuk di sektor ekonomi dan keuangan.

Peristiwa yang menyebabkan penurunan nilai meliputi data dan informasi yang dapat diobservasi langsung. Pengakuan piutang diakui pada laporan posisi keuangan jika perusahaan tersebut menjadi bagian dalam kontrak tersebut. Sedangkan pengukuran piutang berdasarkan biaya perolehan diamortisasi dengan bunga efektif. Pada suatu periode tertentu. Permasalahan pengakuan dan pengukuran serta penyajian saling terkait satu sama lain. Permasalahan ini perlu diteliti pada pemberian kredit PT. Bank Mandiri dengan melakukan penyesuaian dengan PSAK 50 dan PSAK 55. Apabila penurunan nilai pinjaman yang diberikan yang diakui tidak sama dengan yang seharusnya maka ini berarti cadangan yang diukur bisa salah. Hal ini dapat mengakibatkan informasi yang disajikan dalam laporan posisi keuangan tidak tepat dan dapat menyebabkan kesalahan dalam pengambilan keputusan oleh pihak manajemen perusahaan sehingga penting sekali dalam proses pengakuan, pengukuran serta penyajian menggunakan suatu standar sebagai acuan yaitu Standar Akuntansi Keuangan (SAK), khususnya PSAK 50 dan PSAK 55. Standar yang dikeluarkan oleh Ikatan Akuntan Indonesia (IAI) merupakan suatu pedoman dalam penyusunan laporan keuangan untuk tujuan pelaporan bagi pengguna laporan tersebut. Di dalam PSAK 50 dan PSAK 55 diuraikan dan dijelaskan tentang pengakuan, pengukuran, dan penyajian penurunan nilai piutang yang dapat digunakan bagi industri perbankan.

\section{Rumusan Masalah}

Berdasarkan latar belakang masalah yang telah diuraikan dalam penelitian ini, maka rumusan masalah yang akan dibahas yaitu bagaimana penerapan PSAK 50 dan PSAK 55 pada PT. Bank Mandiri Unit Datulolong 1 Manado (PERSERO) Tbk. atas Cadangan Kerugian Penurunan Nilai.

\section{Tujuan Penelitian}

Berdasarkan rumusan masalah di atas, maka tujuan dari penelitian ini adalah untuk mengetahui praktek penerapan PSAK 50 dan PSAK 55 atas Cadangan Kerugian Penurunan Nilai pada PT. Bank Mandiri Unit Datulolong Lasut 1 Manado (PERSERO) Tbk.

\section{Manfaat Penelitian}

Manfaat penelitian yang diperoleh dari penelitian ini adalah :

a) Manfaat Teoritis:

1. Bagi peneliti, memberi manfaat untuk penambahan ilmu pengetahuan mengenai PSAK, dan dapat menjadi referensi untuk penelitian-penelitian selanjutnya dalam bidang perbankan.

b) Manfaat Praktis:

2. Bagi penulis, sebagai sarana untuk menambah wawasan dan pengetahuan mengenai Cadangan Kerugian Penurunan Nilai pada PT. Bank Mandiri Unit Datulolong Lasut 1 Manado (PERSERO) Tbk. apakah telah sesuai dengan PSAK 50 dan PSAK 55 dan sebagai sarana pengembangan ilmu pengetahuan yang secara teoritis dipelajari penulis selama perkuliahan.

3. Bagi perbankan, dari teori dan uraian yang disajikan dalam penulisan ini dapat digunakan sebagai referensi atau informasi oleh Bank yang telah menggunakan PSAK 50 dan PSAK 55 telah sesuai atau masih ada yang harus diperbaiki. 


\title{
TINJAUAN PUSTAKA
}

\begin{abstract}
Akuntansi
Iman Santoso (2010:1) Akuntansi adalah suatu sistem informasi yang mengukur aktivitas-aktivitas bisnis, yang selanjutnya memproses informasi tersebut dalam bentuk laporan keuangan dan mengomunikasikannya kepada para pengambil keputusan (decesion makers).

Dwi Martani (2012:4) Akuntansi menghasilkan infomasi yang menjelaskan kinerja keuangan entitas dalam suatu periode tertentu dan kondisi keuangan entitas pada tanggal tertentu.

Kieso et al (2010 : 2) mendefinisikan akuntansi sebagai suatu sistem dengan input data/informasi dan output berupa informasi dan laporan keuangan yang bermanfaat bagi pengguna internal maupun eksternal entitas.
\end{abstract}

\section{Bank}

Kasmir (2012:3) Bank diartikan sebagai lembaga keuangan yang kegiatan usahanya adalah menghimpun dana dari masyarakat dan menyalurkan kembali dana tersebut ke masyarakat serta memberikan jasa-jasa bank lainnya.

Menurut Undang-undang RI No. 10 Tahun 1998 tanggal 10 November 1998 (Kasmir 2012:112) tentang perbankan, dapat disimpulkan bahwa usaha perbankan meliputi tiga kegiatan, yaitu menghimpun dana, menyalurkan dana, dan memberikan jasa-jasa lainnya. Kegiatan menghimpun dan menyalurkan dana merupakan kegiatan pokok bank sedangkan memberikan jasa bank lainnya hanya kegiatan pendukung.

\section{Kredit}

Kasmir (2012:112) Kredit dalam bahasa latin disebut credere yang artinya percaya. Si pemberi kredit percaya kepada si penerima kredit tersebut, bahwa kredit yang disalurkannya pasti akan dikembalikkan sesuai perjanijan. Sedangkan bagi si penerima kredit berarti menerima kepercayaan, sehingga mempunyai kewajiban untuk membayar kembali pinjaman tersebut sesuai dengan jangka waktunya.

PAPI (2008:117) Kredit adalah penyediaan uang atau tagihan yang dapat dipersamakan dengan itu,berdasarkan persetujuan atau kesepakatan pinjam-meminjam antara bank dan pihak lain yang mewajibkan pihak peminjam untuk melunasi hutangnya setelah jangka waktu tertentu dengan pemberian bunga.

\section{Standar Akuntansi Keuangan (SAK)}

Dwi Martani (2012:15) Standar Akuntansi Keuangan (SAK) digunakan untuk entitas yang memiliki akuntabilitas publik yaitu entitas terdaftar atau dalam proses pendaftaran di pasar modal (yang menggunakan dana masyarakat seperti asuransi, perbankan, dan dana pensiun). Standar ini mengadopsi IFRS melalui IAI, telah menetapkan untuk melakuan adopsi penuh IFRS mulai tahun 2012

Dwi Martani 2012:15 Pernyataan Standar Akuntansi Keuangan berisikan pedoman untuk penyusunan laporan keuangan, pengaturan transaksi atau kejadian, dan komponen tertentu dalam laporan keuangan. Pengaturan terkait komponen laporan keuangan secara umum berisikan definisi, pengakuan, pengukuran, penyajian, dan pengungkapan.

\section{PSAK 50 Instrumen Keuangan : Penyajian}

Sejalan dengan perkembangan terkini standar keuangan yang diterbitkan oleh Dewan Standar Akuntansi Keuangan (DSAK) Ikatan Akuntan Indonesia terutama PSAK 50 :Instrumen Keuangan: Penyajian adopsi dari IAS 32 Financial Instrument Presentation, maka tuntutan bagi perusahan di Indonesia untuk mengadopsi penuh dan menerapkannya dalam penyajian dan penyusunan laporan keuangan sehingga pelaporan keuangan yang disajikan dalam bentuk kuantitatif, dimana informasi yang disajikan didalamnya merupakan sumber utama informasi keuangan yang disampaikan oleh manajemen kepada pihak-pihak di dalam maupun di luar perusahaan sehingga menjadi titik perhatian.

\section{PSAK 55 Instrumen Keuangan: Pengakuan dan Pengukuran}


Dewan Standar Akuntansi Keuangan telah menerbitkan Pernyataan Standar Akuntansi Keuangan (PSAK) 55. PSAK 55 mengenai instrumen keuangan yaitu pengakuan dan pengukuran.Revisi PSAK 55 adalah hasil dari mengadopsi seluruh ketentuan dalam IAS 39 mengenai Recognition and Measurenment of Financial Instrument. Dengan diterbitkannya PSAK 55 ini diharapkan terciptanya proses harmonisasi penyusunan dan analisis laporan keuangan.

\section{Cadangan Kerugian Penurunan Nilai}

Penurunan nilai adalah suatu kondisi dimana terdapat bukti objektif terjadinya peristiwa yang merugikan sebagai akibat dari satu atau lebih peristiwa yang terjadi setelah pengakuan awal kredit tersebut, dan peristiwa yang merugikan tersebut berdampak pada estimasi arus kas masa datang atas aset keuangan atau kelompok aset keuangan yang dapat diestimasi secara andal (Pedoman Akuntansi Perbankan Indonesia, 2008).

Aset keuangan yang diukur dengan harga perolehan diamortisasi serta aset keuangan tersedia untuk dijual dapat mengalami penurunan nilai. Aset keuangan mengalami penurunan nilai apabila tercatat atau biaya perolehan amortisasi lebih tinggi daripada nilai yang dapat diperoleh kembali. Evaluasi atas apakah terdapat bukti objektif penurunan nilai harus dilakukan pada setiap tanggal laporan posisi keuangan. Bila terdapat bukti objektif penurunan nilai maka harus dilakukan estimasi nilai yang dapat diperoleh kembali dan mengakui kerugian penurunan nilai, sebesar selisih nilai yang tercatat dan nilai yang dapat diperoleh kembali.

Bukti objektif oleh Dwi Martani dapat dilihat dari beberapa indikasi berikut:

1. Piutang tidak dilunasi pada saat jatuh tempo.

2. Bunga dan pokok tertunggak dalam beberapa kali termin pembayaran.

3. Pihak pemberi pinjaman memberikan kelonggaran akibat kesulitan keuangan yang dialami pihak peminjam. Kelonggaran diberikan dalam bentuk perpanjangan jangka waktu pelunasan atau penurunan tingkat suku bunga. Restrukrisasi atau keringanan jika peminjam mengalami kesulitan pembayaran.

4. Peminjam dinyatakan pailit oleh pengadilan.

5. Memburuknya kondisi ekonomi yang menyebabkan kemampuan membayar pihak peminjam akan menurun.

6. Kemungkinan bangkrut.

Ketentuan PSAK 55 mengenai pengakuan cadangan kerugian penurunan nilai adalah sebagai berikut:

- PA102. Proses estimasi terhadap jumlah kerugian penurunan nilai dapat menghasilkan satu nilai kerugian atau kisaran (range) nilai kerugian yang mungkin terjadi. Dalam hal yang terakhir, entitas harus mengakui kerugian akibat penurunan nilai sebesar estimasi terbaik dalam kisaran tersebut dengan mempertimbangkan seluruh informasi relevan yang tersedia sebelum laporan keuangan diterbitkan mengenai kondisi yang terjadi pada tanggal neraca.

Evaluasi penurunan nilai menurut Pedoman Akuntansi Perbankan Indonesia (Pedoman Akuntansi Perbankan Indonesia 2008):

1. Secara Individual

2. Secara Kolektif

Pengaruh penurunan nilai dapat diidentifikasi terhadap aset keuangan secara individu maupun secara kelompok aset. Jika secara individual terdapat bukti objektif, maka entitas harus menghitung arus kas masa depan dari aset keuangan tersebut. Selisihnya akan diakui sebagai kerugian penurunan nilai. Jika tidak terdapat bukti objektif penurunan nilai secara individual, maka aset keuangan atau piutang dimasukkan ke dalam kelompok piutang yang memiliki resiko kredit dan menilai penurunan secara kolektif.

Penilaian secara kolektif didasarkan pada kerugian historis piutang dagang. Untuk kebutuhan ini, perusahaan harus mendokumentasikan piutang-piutang yang tidak dapat ditagih untuk keperluan perhitungan penurunan nilai secara kolektif. Perusahaan harus menyimpan data historis untuk piutang yang tidak dapat ditagih sehingga dapat menentukan kemungkinan kerugian kredit. 


\section{Penelitian Terdahulu}

Tabel 1. Penelitian Terdahulu

\begin{tabular}{|c|c|c|c|c|c|c|}
\hline No & $\begin{array}{c}\text { Nama } \\
\text { Peneliti/ } \\
\text { Tahun }\end{array}$ & Judul & Tujuan & $\begin{array}{c}\text { Metode } \\
\text { Penelitian }\end{array}$ & Persamaan & Perbedaan \\
\hline & $\begin{array}{l}1 \text { Ekaputri } \\
\text { (2013) }\end{array}$ & \begin{tabular}{lr}
\multicolumn{2}{l}{ Analisis } \\
Penerapan \\
PSAK & 55 \\
revisi & 2011 \\
atas & CKPN \\
pada & PT. \\
BRI &
\end{tabular} & \begin{tabular}{lr}
\multicolumn{2}{l}{ Bagaimana } \\
penerapan \\
PSAK & 55 \\
atas & CKPN \\
pada & PT. \\
BRI &
\end{tabular} & Deskriptif. & $\begin{array}{l}\text { Peneliti } \\
\text { menggunakan objek } \\
\text { \& tujuan yang sama } \\
\text { yaitu CKPN dalam } \\
\text { bidang perbankan. }\end{array}$ & $\begin{array}{l}\text { Peneliti sebelumnya } \\
\text { tidak meneliti PSAK } \\
50 \quad \text { mengenai } \\
\text { penyajian CKPN. }\end{array}$ \\
\hline & $\begin{array}{l}2 \text { Emanuela } \\
(2012)\end{array}$ & $\begin{array}{l}\text { Analisis } \\
\text { penerapan } \\
\text { PSAK 50 \& } \\
\text { PSAK } 55 \\
\text { atas } \\
\text { impairment } \\
\text { piutang pada } \\
\text { perusahaan } \\
\text { multifinance }\end{array}$ & $\begin{array}{l}\text { Mengetahui } \\
\text { dampak yang } \\
\text { timbul akibat } \\
\text { munculnya } \\
\text { penurunan } \\
\text { piutang hasil } \\
\text { dari PSAK } \\
50 \& \text { PSAK } \\
55 \text { bagi } \\
\text { kinerja } \\
\text { perusahaan } \\
\text { multifinance. }\end{array}$ & $\begin{array}{l}\text { Analisis } \\
\text { Komparatif. }\end{array}$ & $\begin{array}{l}\text { Peneliti } \\
\text { menggunakan PSAK } \\
50 \text { \& PSAK } 55 \text { atas } \\
\text { impairment. }\end{array}$ & $\begin{array}{l}\text { Peneliti } \\
\text { menggunakan } \\
\text { beberapa objek } \\
\text { perusahaan } \\
\text { multifinance di BEI } \\
\text { dan menggunakan } \\
\text { metode analisis } \\
\text { komparatif. }\end{array}$ \\
\hline & $\begin{array}{l}3 \text { Secarian } \\
\text { (2012) }\end{array}$ & $\begin{array}{l}\text { Evaluasi } \\
\text { Penerapan } \\
\text { PSAK } \\
\text { 55atas } \\
\text { intrumen } \\
\text { keuangan } \\
\text { pada } \\
\text { perusahaan } \\
\text { ventura. }\end{array}$ & $\begin{array}{l}\text { Mengetahui } \\
\text { apakah } \\
\text { penerapan } \\
\text { PSAK } 55 \\
\text { pada } \\
\text { perusahaan } \\
\text { telah sesuai } \\
\text { dengan } \\
\text { standar. }\end{array}$ & $\begin{array}{l}\text { Deskriptif } \\
\text { kualitatif. }\end{array}$ & $\begin{array}{l}\text { Peneliti } \\
\text { menggunakan PSAK } \\
55 \text { atas intrumen } \\
\text { keuangan. }\end{array}$ & $\begin{array}{l}\text { Penelitian dilakukan } \\
\text { pada perusahaan } \\
\text { ventura. }\end{array}$ \\
\hline
\end{tabular}

Sumber: Data Olahan 2013

\section{METODE PENELITIAN}

\section{Jenis Penelitian}

Dalam penelitian ini menggunakan jenis penelitian deskriptif, yaitu menggambarkan teori yang terdapat di PSAK 50 (revisi 2010) dan PSAK 55 (revisi 2011) dengan praktek penyajian, pengakuan serta pengukuran atas Cadangan Kerugian Penurunan Nilai yang dilakukan pada PT. Bank Mandiri Unit Datulolong Lasut 1 Manado (PERSERO) Tbk.

\section{Tempat dan Waktu Penelitian}

Penelitian ini mengambil data di PT. Bank Mandiri Unit Datulolong Lasut 1 yang beralamat di Jln. Datulolong Lasut No. 15 Manado (PERSERO) Tbk. Waktu penelitian dimulai dari bulan September sampai dengan bulan November tahun 2013. 


\section{Prosedur Penelitian}

Langkah-langkah yang dilakukan untuk melakukan penelitian, yaitu sebagai berikut:

1. Melakukan permohonan izin penelitian pada PT. Bank Mandiri Unit Datulolong Lasut 1 Manado (PERSERO) Tbk.

2. Melakukan wawancara dengan pihak bank yaitu kepala bagian kredit mikro Bank Mandiri Unit Datulolong Lasut 1

3. Mengumpulkan data yang diperlukan

4. Melakukan proses olah data dan analisis data mengenai pergerakan kredit

5. Membuat hasil dan pembahasan penelitian

6. Membuat kesimpulan dan saran untuk Bank Mandiri

7. Memberikan hasil penelitian kepada Bank Mandiri

\section{Populasi dan Sampel}

Sugiyono (2010:115) menyatakan populasi adalah wilayah generalisasi yang terdiri atas objek/subjek yang mempunyai kualitas dan karakteristik tertentu yang ditetapkan oleh peneliti untuk dipelajari dan kemudian ditarik kesimpulan keseluruhan subjek penelitian. Populasi bukan hanya orang tetapi juga objek dan bedan-benda alam yang lain. Pengertian sampel menurut Sugiyono (2010:116) menyatakan bahwa sampel adalah bagian dari jumlah karakteristik yang dimiliki oleh populasi tersebut. Apa yang dipelajari dari sampel itu, kesimpulannya akan dapat diberlakukan untuk populasi. Sampel yang diambil dari populasi harus bersifat representif atau mewakili.

Berdasarkan uraian tersebut maka penelitian ini menggunakan populasi tahun 2000-2012 pada PT. Bank Mandiri dengan sampel berupa data pergerakan pinjaman pada tahun 2010-2012.

\section{Metode Pengumpulan Data}

Metode pengumpulan data terbagi dalam jenis data, sumber data, dan teknik pengumpulan data:

\section{Jenis Data}

Menurut Sugiyono (2010:13) dalam penelitian ada dua jenis data yang digunakan yaitu data kuantitaif dan data kualitatif adalah sebagai berikut :

1. Data kuantitatif dapat diartikan sebagai metode penelitian yang berlandaskan pada filsafat positivism, digunakan untuk meneliti pada populasi atau sampel tertentu, teknik pengambilan sampel pada umunya dilakukan secara random, pengumpulan data menggunakan intrumen penelitian, analisis data bersifat kuantitatif/statistik dengan tujuan untuk menguji hipotesis yang telah ditetapkan. Dalam penelitian ini, data kuantitatif berupa data pergerakan pinjaman atau kredit PT. Bank Mandiri Unit Datulolong Lasut 1 Manado. (PERSERO) Tbk.

2. Data kualitatif dapat diartikan metode penelitian yang berlandaskan pada filsafat postivisme, digunakan untuk meneliti pada kondisi objek yang alamiah, dimana peneliti adalah sebagai instrumen kunci, pengambil sampel sumber data dilakukan secara purposive dan snowball, teknik pengumpulan dengan trianggulasi, analisis data bersifat induktif/kualitatif, dan hasil penelitian kualitatif lebih menekankan makna dari pada generalisasi. Dalam penelitian ini, data kualitatif adalah data yang disajikan deskriptif atau berbentuk uraian berupa sejarah dan struktur organisasi PT. Bank Mandiri Unit Datulolong Lasut 1 Manado (PERSERO) Tbk.

\section{Sumber Data}

Supardi (2013:16) menyatakan bahwa pengumpulan data dapat menggunakan dua sumber yaitu sumber primer dan sumber sekunder sebagai berikut;

1. Sumber primer adalah sumber data yang diperoleh atau dikumpulkan langsung oleh orang yang melakukan penelitian atau yang bersangkutan yang memerlukannya. Data primer disebut juga data asli atau data baru. Dalam hal ini peneliti menggunakan data primer yang berasal dari bagian kredit mikro PT. Bank Mandiri Unit Datulolong Lasut 1 berupa data pergerakan kredit.

2. Sumber sekunder merupakan sumber yang tidak langsung memberikan data kepada pengumpul data. Data yang diperoleh atau dikumpulkan dari sumber-sumber yang telah ada. Data sekunder yang 


\section{Teknik Pengumpulan Data}

digunakan peneliti di dalam penelitian ini berasal dari buku-buku yang bersangkutan dengan judul penelitian dan jurnal skripsi peneliti sebelumnya.

1. Survei adalah kegiatan awal yang peneliti lakukan untuk meneliti permasalahan yang sedang dihadapi oleh perusahaan seperti sejarah dan kondisi perusahaan pada saat ini. Dalam hal ini peneliti memilih PT. Bank Mandiri Unit Datulolong Lasut 1 sebagai objek penelitian. Permasalahan yang dihadapi oleh perusahaan kemudian diangkat sebagai judul penelitian dengan menentukan rumusan masalah agar penelitian menjadi lebih fokus.

2. Dokumentasi yang didapat dari pengumpulan data dan informasi melalui buku-buku, jurnal, internet dengan melakukan penelitian terhadap catatan atau dokumen yang ada seperti sejarah perusahaan dan pergerakan kredit yang disajikan oleh PT. Bank Mandiri Unit Datulolong Lasut 1.

3. Wawancara yang berupa pertemuan dua orang untuk bertukar informasi dan ide melalui tanya jawab, sehingga dapat dikonstruksikan makna dalam suatu topik tertentu, Sugiyono (2010: 410). Peneliti menggunakan teknik wawancara untuk mengajukan beberapa pertanyaan mengenai proses pemberian kredit, pengakuan awal dan pengukuran piutang, pembentukan cadangan penurunan nilai serta penyajiannya. Dalam hal ini, peneliti melakukan wawancara terhadap Kepala Bagian Kredit Mikro PT. Bank Mandiri Unit Datulolong Lasut 1 Manado.

\section{Metode Analisis}

Metode yang digunakan untuk menganalisis data dalam pembahasan ini adalah adalah metode deskriptif yaitu dengan cara mendeskripsikan atau menggambarkan data yang telah terkumpul sebagaimana adanya tentang penerapan PSAK 50 dan PSAK 55 atas cadangan kerugian penurunan nilai pada perusahaan untuk kemudian dibandingkan dengan teori yang ada sehingga mampu memberikan informasi dan kesimpulan yang lebih luas.Sugiyono (2010:206)

\section{Definisi Operasional}

1. PSAK 50 adalah merupakan pernyataan standar akuntansi keuangan yang mengatur tentang instrumen keuangan: penyajian. Semua paragraf yang terdapat dalam PSAK 50 memiliki kekuatan mengatur Pernyataan tersebut wajib diterapkan. Instrumen keuangan adalah setiap kontrak yang menambah nilai aset keuangan entitas dan kewajiban keuangan atau instrumen ekuitas entitas lain.

2. PSAK 55 adalah pernyataan standar akuntansi keuangan yang mengatur tentang Instrumen keuangan: pengakuan dan pengukuran. Yang mengadopsi seluruh ketentuan dalam IAS 39 FinancialInstrumens: Recognation and Measurement.

3. Cadangan Kerugian Penurunan Nilai adalah cadangan yang wajib dibentuk bank jika terdapat bukti obyektif mengenai penurunan nilai atas aset keuangan atau kelompok aset keuangan sebagai akibat dari satu atau lebih peristiwa yang terjadi setelah pengakuan awal aset tersebut (peristiwa yang merugikan) dan berdampak pada estimasi arus kas masa depan. Jumlah cadangan kerugian diukur sebagai selisih antara nilai tercatat aset keuangan dengan nilai kini estimasi arus kas masa depan yang didiskonto menggunakan suku bunga efektif awal dari aset keuangan. Dalam penelitian ini, peneliti akan meneliti mengenai pencatatannya dan mengevaluasi pembentukan nilai yang telah terbentuk atas cadangan kerugian penurunan nilai sesuai dengan PSAK No. 55 (Revisi 2011).

\section{HASIL PENELITIAN DAN PEMBAHASAN}

\section{Sejarah PT. Bank Mandiri}

Bank Mandiri didirikan pada tanggal 2 Oktober 1998 sebagai bagian dari program restrukturisasi perbankan yang dilaksanakan oleh Pemerintah Indonesia. Pada bulan Juli 1999, empat bank milik Pemerintah yaitu Bank Bumi Daya, Bank Dagang Negara, Bank Expor Impor Indonesia dan Bank Pembangunan Indonesia, digabung ke dalam Bank Mandiri, dimana masing-masing bank tersebut memiliki peran yang tak terpisahkan dalam pembangunan perekonomian Indonesia. Sampai dengan hari ini, Bank Mandiri meneruskan tradisi selama lebih dari 140 tahun memberikan kontribusi dalam dunia perbankan dan perekonomian Indonesia. 
Visi dan Misi PT. Bank Mandiri (PERSERO) Tbk.

Setiap perusahaan memiliki visi dan misi untuk menunjang kelangsungan tujuan perusahaan.Demikian juga dengan PT. Bank Mandiri.

a. Visi :

TERDEPAN. TERPERCAYA, TUMBUH BERSAMA ANDA

b. Misi :

- Berorientasi pada pemenuhan kebutuhan pasar

- Mengembangan sumber daya manusia professional

- Memberikeuntungan yang maksimal bagi stakeholder

- Melaksanakan manajemen terbuka

- Peduli terhadap kepentingan masyarakat dan lingkungan

\section{Pinjaman yang diberikan}

Pinjaman yang diberikan PT. Bank Mandiri Unit Datulolong Lasut 1 Manado adalah aset keuangan dengan pembayaran tetap atau telah ditentukan. Pada saat pengakuan awal, pinjaman yang diberikan dan piutang diakui pada nilai wajarnya diukur pada biaya perolehan diamortisasi dengan menggunakan metode suku bunga efektif. Pendapatan dari aset keuangan dalam kelompok pinjaman yang diberikan dan piutang dicatat di dalam laporan laba rugi.PT. Bank Mandiri melaporkan kerugian penurunan nilai sebagai pengurang dari nilai tercatat dari aset keuangan termasuk dalam kelompok pinjaman yang diberikan dan piutang, serta diakui di dalam laporan laba rugi sebagai pembentukan cadangan kerugian penurunan nilai.

\section{Penyajian}

Bank Mandiri menggunakan akuntansi tanggal penyelesaian untuk transaksi aset keuangan. Nilai piutang yang disajikan dalam laporan keuangan adalah nilai setelah dikurangi dengan cadangan kerugian penurunan nilai. Piutang disajikan dalam aset lancar dengan kategori pinjaman yang diberikan. Aset keuangan yang dialihkan kepada pihak ketiga tetapi tidak memenuhi syarat penghentian pengakuan disajikan di dalam neraca sebagai aset yang dijaminkan jika pihak penerima memiliki hak untuk menjual atau mentransfer kembali.

\section{Pengakuan}

Aset keuangan yang dicatat berdasarkan biaya perolehan diamortisasi. Pada setiap tanggal neraca, Bank Mandiri mengevaluasi apakah terdapat bukti yang objektif bahwa aset keuangan mengalami penurunan nilai. Jaminan agunan diakui dalam laporan posisi keuangan, jika pihak penerima memiliki hak untuk menjual Pengakuan nilai kini dari estimasi arus kas masa datang atas aset keuangan dengan agunan mencerminkan arus kas yang dapat dihasilkan dari pengambilalihan agunan dikurangi biaya-biaya untuk memperoleh dan menjual agunan.

\section{Pengukuran}

Pengukuran tingkat penurunan nilai kolektif untuk aset keuangan dihitung berdasarkan kerugian historis yang pernah dialami atas aset-aset yang memiliki karakteristik risiko kredit yang sama. Bank Mandiri menggunakan metode pencadangan menghapus piutang tak tertagih dengan mendebit cadangan kerugian penurunan nilai dan mengkredit piutang. Estimasi kerugian atas aset keuangan dimasa yang akan datang dikaji secara berkala untuk mengurangi perbedaan antara estimasi jumlah kerugian dengan jumlah kerugian aktualnya.

\section{Pembentukan cadangan penurunan nilai}

Bank Mandiri membentuk cadangan kerugian penurunan nilai jika terdapat bukti objektif adanya penurunan nilai untuk pinjaman yang diberikan pada periode tertentu dengan menghitung NPL (non performing loan) atau kredit bermasalah, Bank Mandiri terlebih dahulu menentukan presentase kredit bermasalah setiap periode pinjaman kemudian menetapkan probability of default untuk kredit bermasalah tersebut selanjutnya mengalikan saldo awal pinjaman dengan presentase probality of default tersebut. Hasil dari perhitungan tersebut merupakan cadangan kerugian penurunan nilai. Semakin tinggi presentase kredit bermasalah maka semakin tinggi cadangan kerugian 
penurunan nilai yang harus dibentuk, sebaliknya semakin rendah presentase kredit bermasalah maka semakin rendah pula cadangan kerugian penurunan nilai yang dibentuk dan menandakan Bank Mandiri mengalami ekspansi kredit yang bai dan sehat.Setelah cadangan dibentuk maka dilakukan pencatatan ayat jurnal dengan mendebit beban penurunan nilai piutang dan mengkredit cadangan kerugian penurunan nilai.

Kriteria yang digunakan oleh Bank Mandiri untuk menentukan bukti objektif dari penurunan nilai adalah sebagai berikut:

1. Kesulitan keuangan signifikan yang dialami penerbit atau pihak peminjam.

2. Pelanggaran kontrak, seperti terjadinya wanprestasi atau tunggakan pembayaran pokok atau bunga.

3. Pihak pemberi pinjaman, dengan alasan ekonomi atau hukum sehubungan dengan kesulitan keuangan yang dialami pihak peminjam, memberikan keringanan(konsesi) pada pihak peminjam yang tidak mungkin diberikan jika pihak peminjamtidak mengalami kesulitan tersebut.

4. Terdapat kemungkinan bahwa pihak peminjam akan dinyatakan pailit ataumelakukan reorganisasi keuangan lainnya.

5. Hilangnya pasar aktif dari aset keuangan akibat kesulitan keuangan.

6. Data yang dapat diobservasi mengindikasikan adanya penurunan yang dapat diukur atas estimasi.

\section{Prosentase Probability of Default}

Tabel 2. Prosentase Probability of Default

\begin{tabular}{cccccc}
\hline $\begin{array}{c}\text { Periode } \\
\text { Pinjaman }\end{array}$ & Total Pinjaman & Lancar & DPK & NPL & $\begin{array}{c}\text { Probability } \\
\text { of } \\
\text { Default }\end{array}$ \\
\hline 2010 & 8.735 & $73,73 \%$ & $13,98 \%$ & $12,29 \%$ & \\
2011 & 9.705 & $91,14 \%$ & $7,05 \%$ & $1,81 \%$ & $0,705 \%$ \\
2012 & 16.363 & $95,47 \%$ & $3,81 \%$ & $0,72 \%$ & $0,1265 \%$ \\
\hline
\end{tabular}

Sumber : Data Perusahaan 2010-2012

Tabel 2 menunjukan persentase pergerakan saldo pinjaman tahun 2010-2012.Jika dilihat pada tabel untuk kategori pinjaman lancar atau kredit yang tidak bermasalah mengalami peningkatan setiap periode, selanjutnya untuk kategori pinjaman dalam perhatian khusus (DPK) atau kredit yang mulai bermasalah presentasinya baik karena terjadi penurunan setiap periode. Begitu juga dengan Non Performing Loan (NPL) atau kategori kredit bermasalah mengalami penurunan dari 12,29\% hingga 0,72\%. Jika bobot NPL > 12,5\% maka bank akan mengalami kerugian karena berpengaruh pada kualitas kesehatan bank.

\section{Perhitungan Cadangan Kerugian Penurunan Nilai}

Tabel 3. Perhitungan Cadangan Kerugian Penurunan Nilai (CKPN)

\begin{tabular}{cccc}
\hline Tahun & Saldo Awal & $\begin{array}{c}\text { Probability of } \\
\text { Default }\end{array}$ & CKPN \\
\hline 2011 & 9.705 .000 .000 & $0,705 \%$ & 6.842 .025 .000 \\
\hline 2012 & 16.363 .000 .000 & $0,1265 \%$ & 2.069 .919 .500 \\
\hline
\end{tabular}

Sumber: Data Olahan 2010-2012

Keterangan:

Cadangan kerugian penurunan nilai: Saldo Awal x PD

Tabel 3 di atas menjelaskan tentang perhitungan cadangan penurunan nilai.Tahun 2011 didapatkan penyisihan aktiva sebesar Rp. 6.842.025.000 karena jumlah probability of default 0,705\%. Tahun terakhir penyisihan aktiva yang didapatkan sebesar Rp. 2.069.919.500 karena probability of default sangat rendah sebesar $0,1265 \%$. 
Tabel 2 dan tabel 3 di atas saling berhubungan karena dengan persentase probability of default dapat diketahui kemungkinan kerugian yang kemudian akan dikalikan dengan saldo awal pinjaman agar dapat diketahui berapa besarnya biaya yang harus dicadangkan oleh Bank Mandiri dalam menentukan besarnya nilai penyisihan atau cadangan dana dari kredit bank pada tahun berikutnya.

\section{Pembahasan}

Tabel 4. Perbandingan penyajian CKPN berdasarkan PSAK 50 (Revisi 2010) dengan PT. Bank Mandiri Unit Datulolong Lasut 1 Manado (PERSERO) Tbk.

\begin{tabular}{|c|c|c|c|}
\hline No. & $\begin{array}{c}\text { Berdasarkan } \\
\text { PSAK } 50 \text { (Revisi 2010) }\end{array}$ & $\begin{array}{c}\text { Berdasarkan } \\
\text { PT. Bank Mandiri }\end{array}$ & Kesimpulan \\
\hline 1 & $\begin{array}{l}\text { Piutang disajikan dalam laporan posisi } \\
\text { keuangan sebesar nilai } \\
\text { dikurangi } \\
\text { penurunan nilai. }\end{array}$ & $\begin{array}{l}\text { Nilai piutang yang disajikan dalam } \\
\text { laporan keuangan adalah nilai setelah } \\
\text { dikurangi dengan cadangan kerugian } \\
\text { penurunan nilai }\end{array}$ & Sesuai \\
\hline 2 & $\begin{array}{l}\text { Catatan atas laporan keuangan } \\
\text { menjelaskan kebijakan akuntansi, } \\
\text { rincian piutang menurut jenis, } \\
\text { rekonsiliasi cadangan piutang, dan } \\
\text { informas khusus terkait piutang } \\
\text { seperti piutang dijaminkan dan } \\
\text { penjelasan rinci debitur tertentu dukur } \\
\text { nilai wajar }\end{array}$ & $\begin{array}{l}\text { Penyajian ikhtisar kebijakan akuntansi } \\
\text { bank, asset keuangan diukur pada nilai } \\
\text { wajar serta penjelasan pinjaman } \\
\text { yangdiberikan dan klasifikasi cadangan } \\
\text { kerugian penurunan nilai. }\end{array}$ & Sesuai \\
\hline & $\begin{array}{l}\text { Piutang disajikan dalam kategori kredit } \\
\text { atau pinjaman yang diberikan. }\end{array}$ & 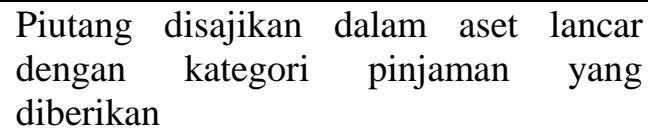 & Sesuai \\
\hline
\end{tabular}

Sumber : Data Olahan 2013

Tabel 5. Perbandingan pengakuan atas CKPN berdasarkan PSAK 55 (Revisi 2011) dengan PT. Bank Mandiri Unit Datulolong Lasut 1 Manado (PERSERO) Tbk.

\begin{tabular}{|c|c|c|}
\hline $\begin{array}{c}\text { Berdasarkan } \\
\text { PSAK } 55 \text { (Revisi 2011) }\end{array}$ & $\begin{array}{c}\text { Berdasarkan } \\
\text { PT. Bank Mandiri }\end{array}$ & Kesimpulan \\
\hline $\begin{array}{l}\text { 1. Laporan posisi keuangan mengakui } \\
\text { aset yang dijaminkan jika pihak } \\
\text { penerima memiliki hak untuk menjual } \\
\text { atau mentransfer kembali. }\end{array}$ & $\begin{array}{l}\text { Jaminan agunan diakui dalam laporan } \\
\text { posisi keuangan konsolidasian, jika } \\
\text { pihak penerima memiliki hak untuk } \\
\text { menjual }\end{array}$ & Sesuai \\
\hline $\begin{array}{l}\text { 2. Penurunan nilai diukur berdasarkan } \\
\text { biaya perolehan yang diamortisasi } \\
\text { dengan menggunakan suku bunga } \\
\text { efektif. }\end{array}$ & $\begin{array}{l}\text { Pada biaya perolehan diamortisasi } \\
\text { dengan menggunakan metode suku } \\
\text { bunga efektif. }\end{array}$ & Sesuai \\
\hline $\begin{array}{l}\text { 3. Evaluasi piutang pada setiap tanggal } \\
\text { neraca jika terdapat bukti objektif } \\
\text { pengakuan kerugian penurunan nilai. }\end{array}$ & $\begin{array}{l}\text { Piutang dicek satu per satu pada setiap } \\
\text { tanggal neraca untuk evaluasi adanya } \\
\text { bukti objektif penurunan nilai. }\end{array}$ & Sesuai. \\
\hline $\begin{array}{l}\text { 4. Perhitungan nilai kini dari estimasi } \\
\text { arus kas masa depan atas asset } \\
\text { keuangan. }\end{array}$ & $\begin{array}{lcr}\text { Pengakuan arus kas masa } & \text { depan } \\
\text { berdasarkan } & \text { pengambilalihan } & \text { agunan } \\
\text { dikurangi } & \text { biaya-biaya } & \text { untuk } \\
\text { memperoleh dan menjual agunan. }\end{array}$ & Sesuai. \\
\hline
\end{tabular}


Sumber : Data Olahan 2013

Tabel 6. Perbandingan pengukuran atas CKPN berdasarkan PSAK 55 (Revisi 2011) dengan PT. Bank Mandiri Unit Datulolong Lasut 1 (PERSERO) Tbk.

\begin{tabular}{|c|c|c|c|}
\hline No. & $\begin{array}{l}\text { Berdasarkan } \\
\text { PSAK } 55 \text { (Revisi 2011) }\end{array}$ & $\begin{array}{c}\text { Berdasarkan } \\
\text { PT. Bank Mandiri } \\
\end{array}$ & Kesimpulan \\
\hline 1. & $\begin{array}{l}\text { Melakukan penurunan nilai sesuai } \\
\text { ketentuan penurunan nilai aset } \\
\text { keuangan diukur pada biaya perolehan } \\
\text { diamortisasi }\end{array}$ & $\begin{array}{l}\text { Pengukuran setelah tanggal perolehan } \\
\text { membutuhkan perhitungan amortisasi } \\
\text { diskon dan premium setiap tanggal } \\
\text { pelaporan. }\end{array}$ & Sesuai. \\
\hline 2. & $\begin{array}{l}\text { Arus kas masa depan dari kelompok } \\
\text { aset keuangan yang penurunan nilainya } \\
\text { dievaluasi secara kolektik dihitung } \\
\text { berdasarkan data historis beberapa } \\
\text { tahun sebelumnya. }\end{array}$ & $\begin{array}{l}\text { Tingkat penurunan nilai kolektif untuk } \\
\text { aset keuangan dihitung berdasarkan } \\
\text { kerugian historis. }\end{array}$ & Sesuai. \\
\hline 3. & $\begin{array}{l}\text { Metode pengukuran pencatatan } \\
\text { penurunan nilai: metode penghapusan } \\
\text { langsung dan metode pencadangan. }\end{array}$ & $\begin{array}{l}\text { Menggunakan metode pencadangan } \\
\text { menghapus piutang tak tertagih dengan } \\
\text { mendebit cadangan kerugian penurunan } \\
\text { nilai dan mengkredit piutang. }\end{array}$ & Sesuai. \\
\hline 4. & $\begin{array}{l}\text { Estimasi arus kas masa depan dikaji } \\
\text { ulang secara berkala. }\end{array}$ & $\begin{array}{l}\text { Estimasi kerugian atas asset keuangan } \\
\text { dimasa yang akan datang dikaji secara } \\
\text { berkala untuk mengurangi perbedaan } \\
\text { antara estimasi jumlah kerugian dengan } \\
\text { jumlah kerugian aktualnya. }\end{array}$ & Sesuai. \\
\hline
\end{tabular}

Sumber : Data Olahan 2013

\section{PENUTUP}

\section{Kesimpulan}

Berdasarkan hasil penelitian dan pembahasan, maka penulis mengemukakan kesimpulan sebagai berikut:

Dalam penerapan PSAK 50 (Revisi 2010) dan PSAK 55 (Revisi 2011) atas Cadangan Kerugian Penurunan Nilai oleh PT. Bank Mandiri Unit Datulolong Lasut 1 Manado (PERSERO) Tbk. telah sesuai dengan standar yang berlaku. Proses pengakuan awal Cadangan Kerugian Penurunan Nilai PT. Bank Mandiri sebesar nilai diamortisasi dikurangi kerugian penurunan nilai. Amortisasi menggunakan suku bunga efektif yang menyamakan nilai wajar dengan nilai kini arus kas dari pembayaran piutang dan bunganya di masa depan. Sedangkan pada proses pengukuran penurunan nilai aset keuangan secara kolektif didasarkan pada data historis beberapa tahun sebelumnya. Kemudian, piutang disajikan dalam laporan posisi keuangan sebesar nilai diamortisasi dikurangi cadangan kerugian penurunan nilai.

\section{Saran}

Penulis mengemukakan saran-saran sebagai berikut:

1. Dalam proses penyajian, pengakuan, dan pengukuran cadangan kerugian penurunan nilai untuk aset keuangan piutang PT. Bank Mandiri Unit Datulolong Lasut 1 Manado (PERSERO) Tbk. sudah sesuai dengan PSAK 50 dan 55 juga telah diterapkan dengan baik. Diharapkan dipertahankan dan diterapkan secara konsisten disetiap periode akuntansi agar menghasilkan laporan keuangan yang lebih akurat dalam mencerminkan posisi keuangan, prinsip transparansi dan hasil operasi perusahaan. 
2. Dalam pencatatan piutang, sebaiknya perusahaan menetapkan kebijakan terhadap penyisihan piutang ragu-ragu agar perusahaan dapat mencegah terjadinya piutang tak tertagih akibat pelanggan yang pailit untuk suatu saat yang tidak diharapkan.

\section{DAFTAR PUSTAKA}

Bank Indonesia.2008. Pedoman Akuntansi Perbankan Indonesia.http://auditmepostblogspot.com2010/01/pedoman akuntansi-perbankan-indonesia.html. Diakses 27, Agustus 2013

Dwi Martani, Sylvia Veronica NPS, Ratna Wardhani, Aria Farahmita, Edward Tanujaya.2012 Akuntansi Keuangan Menengah. Berbasis PSAK. Penerbit Salemba Empat. Jakarta.

Ekaputri C. Febriati. 2013. Analisis Penerapan PSAK 55 atas Cadangan Kerugian Penurunan Nilai Pada PT. Bank BRI.Jurnal EMBA Vol 1, No. 3, Hal.207-217.

Emanuela. 2012. Analisis Penerapan PSAK 50 \& PSAK 55 atas Impairment Piutang Pada Perusahaan Multifinance.Jurnal FE UI.

Ikatan Akuntansi Indoneisia. 2012. Standar Akuntansi Keuangan. Penerbit Salemba Empat. Jakarta.

Iman Santoso. 2010. Akuntansi Keuangan Menengah. Penerbit PT. Refika Aditama.Bandung.

Kasmir, SE, MM. 2012.Dasar-Dasar Perbankan.,Edisi Revisi. PT . Raja Grafindo Persada.Jakarta.

Maryanto Supriyono. 2011. Buku Pintar Perbankan. Penerbit Andi. Yogyakarta.

Secarian. 2012. Evaluasi Penerapan PSAK 55 Instrumen Keuangan Pada PT. ABC Ventura. Jurnal Akuntansi. Vol 1, No. 2, Hal.1-14.

Steven M. Bragg. 2012. IFRS Made Easy. Indeks.Jakarta

Sugiyono. 2010. Metode Penelitian Bisnis (Pendekatan Kuantitatif, Kualitatif, dan R\&D).Alfabeta.Bandung

Supardi, 2013.Aplikasi Statistika dalam Penelitian. Smart. Jakarta 